scholars of Swiss literature and historians of medicine, respectively. Cumulatively, the book presents a stimulating cross-section of cultural history, religious history, medical history and literary studies, and provides a fascinating and richly nuanced picture of the social and professional networks that fostered change and innovation in sixteenth-century Zurich.

JENNIFER SPINKs, The University of Melbourne

\title{
Lyrics of the French Renaissance: Marot, Du Bellay, Ronsard
}

Translated by Norman R. Shapiro with an introduction by Hope Glidden Chicago: University of Chicago Press, 2006. Pp. xxvi, 384

Shapiro's consummate translations of selected sixteenth-century French lyrics, first published in 2002 in hardback, are now available in paperback. French originals and English translations are given side-by-side, and there are occasional, though not systematic, footnotes about language, poetic form, biography, or historical events. Hope Glidden's introduction provides enough context for non-specialists while offering some thought-provoking insights for more initiated readers. However, one sometimes has the impression that Glidden's text has been truncated or edited; a significantly longer introduction, doing justice to her considerable expertise, would have been preferable. The selection of poems mostly respects the diversity of the poets' output, and includes poems from some collections scarcely read today (Ronsard's Gayetez or Du Bellay's Sonnets divers, for example). The space given to Marot is most welcome; he is presented unequivocally as being as important an influence on vernacular lyric as Du Bellay and Ronsard. The lack of selections from Ronsard's polemical discourses is regrettable, as is the omission of Marot's L'Enfer or his French Psalms. Marot's epigrams, on the other hand, seem overrepresented (70 pages, compared to only 16 pages of his epistles). But the selections made are understandable from a translator's point of view: Shapiro's skills shine most, and he perhaps catches most the spirit of the original, when he is rendering pithy, witty verse. It is as an exercise in translation, and as a gloss on the sixteenth-century practice of imitation itself, that this book is most impressive. Shapiro maintains the rhyme and meter of the original, and otherwise seeks to imitate in the Renaissance sense of the word, acknowledging his debt to his models while not giving slavishly literal equivalents. Readers using the book as a scholarly tool will wish for more apparatus: a bibliography would certainly be helpful, more footnotes, and publication dates for the collections represented. Nevertheless, the 
book represents a well-executed translatio studii from an important poetic corpus, and fills a significant gap for generalist Anglophone readers of poetry and Renaissance specialists who don't read French.

LOUISA MACKENZIE, University of Washington, Seattle 